\title{
Melt pond distribution and geometry in high Arctic sea ice derived from aerial investigations
}

\author{
W. HUANG, ${ }^{1}$ P. LU, ${ }^{2}$ R. LEI, ${ }^{3}$ H. XIE, ${ }^{4}$ Z. $\mathrm{LI}^{2}$ \\ ${ }^{1}$ School of Environmental Science and Engineering, Chang'an University, Xi'an 710054, P.R. China \\ E-mail: huangwenfeng@chd.edu.cn \\ ${ }^{2}$ State Key Laboratory of Coastal and Offshore Engineering, Dalian University of Technology, Dalian 116024, P.R. China \\ ${ }^{3}$ Key Laboratory for Polar Science of the State Oceanic Administration, Polar Research Institute of China, Shanghai \\ 200136, China \\ ${ }^{4}$ Laboratory for Remote Sensing and Geoinformatics, University of Texas at San Antonio, TX 78249, USA
}

\begin{abstract}
Aerial photography was conducted in the high Arctic Ocean during a Chinese research expedition in summer 2010. By partitioning the images into three distinct surface categories (sea ice/ snow, water and melt ponds), the areal fraction of each category, ice concentration and the size and geometry of individual melt ponds, are determined with high-spatial resolution. The ice concentration and melt pond coverage have large spatial deviations between flights and even between images from the marginal ice zone to the pack ice zone in the central Arctic. Ice concentration and pond coverage over high Arctic (from $84^{\circ} \mathrm{N}$ to north) was $\sim 75 \%$ and $\sim 6.8 \%$, respectively, providing 'ground truth' for the unusual transpolar reduction strip of ice indicated concurrently by AMSR-E data and for the regions (north of $88^{\circ} \mathrm{N}$ ) where no passive microwave sensors can cover. Melt pond size and shape distributions are examined in terms of pond area $(S)$, perimeter $(P)$, mean caliper dimension (MCD) $(L)$, roundness $(R)$, convex degree $(C)$, the ratio of $P / S$ and fractal dimension $(D)$. Power-law relationships are developed between pond size and number. Some general trends in geometric metrics are identified as a function of pond area including $R, C, P / S$ and $D$. The scale separation of pond complexity is demonstrated by analyzing area-perimeter data. The results will potentially help the modelling of melt pond evolution and the determination of heterogeneity of under-ice transmitted light fields.
\end{abstract}

KEYWORDS: aerial photography, geometry, high Arctic Ocean, melt pond, sea ice

\section{INTRODUCTION}

Substantial decreases in Arctic sea ice in terms of ice extent and thickness have been found and confirmed by both in situ measurements and remote sensing. Annual minimum ice extent in September declined with an average rate of 7.8\% per decade over the last 50 a (Ogi and Rigor, 2013; Stocker and others, 2013). An accelerated declining of summer Arctic sea ice is also a robust feature of satellite data from recent years (Kinnard and others, 2008; Laxon and others, 2013; Xia and others, 2014).

Since climate warming is amplified in the Arctic Ocean due to albedo feedback mechanism, Arctic sea ice is widely regarded as a sensitive indicator of climate change, as well as being a vital climate component. Arctic sea ice is also one of the main requirements for accurate simulations of the atmosphere/ocean interaction system, which is the key process in global climate models (GCMs). For instance, the ice-albedo feedback would delay the onset of sea ice refreezing season (Lei and others, 2014). A wide variety of snow and sea ice albedo parameterization schemes have promoted the understanding of the role of sea ice in climatological and biogeochemical processes and are currently used in GCMs (Flocco and others, 2012; Eicken, 2013; Tietsche and others, 2014). However, based on limited field observations that do not account for the horizontal heterogeneity of ice types, most of them are quite simplistic, and are unable to capture the annual cycle of sea ice albedo. For instance, the Intergovernmental Panel on Climate Change AR5 highlighted the inability of models to simulate the currently observed rapid reduction of sea ice extent (Stocker and others, 2013). The inability of GCMs indicates the need for a more realistic representation of ice-albedo feedback, which is highly dependent upon quantifying the melt pond evolution and applying the correct albedo for each phase of pond evolution (Flocco and others, 2012; Perovich and Polashenski, 2012; Roeckner and others, 2012).

Melt ponds are a pervasive and persistent surface feature of the summertime Arctic sea ice. Melt ponds are pools of water, which is accumulated in the topographical depressions of sea ice due to surface melt of snow and sea ice. This process is driven by increased solar insolation in summer. The formation and refreeze-up of melt ponds leads to rapid fluctuations in the surface albedos, enhancing their seasonal variability and making the parameterization of regional albedo more difficult (Perovich and others, 2003; Eicken and others, 2004; Light and others, 2008; Arndt and Nicolaus, 2014; Xia and others, 2015).

Skyllingstad and others (2009) demonstrated that the decrease in pond albedo from pond deepening has a much lower influence on the total albedo than pond coverage. Currently extensive mapping of melt pond coverage (such as at a pan-Arctic scale) can be retrieved from balloon/ship/airborne photography (Inoue and others, 2008a; Lu and others, 2010; Sankelo and others, 2010; Renner and others, 2013; Webster and others, 2015), optical spaceborne sensors 
(Tschudi and others, 2008; Rösel and Kaleschke, 2012; Rösel and others, 2012), and tentatively synthetic aperture radars (SAR) instruments (Yackel and Barber, 2000; Mäkynen and others, 2014; Scharien and others, 2014a, b). Pond physics and mechanisms are preferentially investigated using in situ instrumentation (Perovich and others, 2003; Eicken and others, 2004; Nicolaus and others, 2012; Polashenski and others, 2012; Katlein and others, 2015), such as the fruitful yeararound SHEBA experiments that provided profound understanding of melt pond formation and development, and field datasets for model development and validation (Perovich and others, 1999, 2002b, 2003; Curry and others, 2001; Eicken and others, 2002). Unmixing algorithms based on multi-spectral optical data are a promising method for retrieving large-scale pond fraction (Markus and others, 2003; Tschudi and others, 2008; Rösel and Kaleschke, 2012; Rösel and others, 2012) but they have quite large uncertainties due to prevailing clouds and cannot derive detailed pond geometry, i.e. size and shape, which is important to understand the melt pond development. Besides, high-resolution satellites (e.g. SAR) provide more accurate all-weather ice-surface information (Yackel and Barber, 2000; Kim and others, 2013; Mäkynen and others, 2014; Scharien and others, 2014a, b) but their narrow swath and inability to discriminate between melt ponds and leads enclosed within interconnected ice floes limits their ability to retrieve a basin-scale surface fraction. Medium-resolution optical images, such as, Landsat images, cannot derive pond size or shape either, since many ponds are $<30 \mathrm{~m}$ in diameter. Landsat's low temporal resolution $(\sim 16 \mathrm{~d})$ and incapability of cloud penetration hampers its usage in obtaining a daily or weekly datasets of melt pond coverage (Markus and others, 2003).

Modeling studies (Taylor and Feltham, 2004; Flocco and Feltham, 2007; Scott and Feltham, 2010) require the pond size/area variation (i.e. widening or closing) to be accurately quantified, and the processes involved in pond lateral melting to be understood thoroughly. These processes include, but are not limited to, heat transport within ponds, wind-induced circulations and advective-convective heat fluxes and horizontal seepage or recharge of pond water through pond walls. Using numerical method, Skyllingstad and Paulson (2007) pointed out that pond size and shape significantly influence lateral and bottom melting rates through changing water movement and heat transport within a melt pond, thus affecting the pond area and depth evolution, which are key processes dominating overall ice albedos (Eicken and others, 2004; Huang and others, 2011; Polashenski and others, 2012).

Melt ponds also play a key role, with respect to their size and spatial distributions, in the solar radiation partitioning and heat and salt transports within the 'atmosphere-melt pond-sea ice-upper ocean' column in several ways, for instance, affecting light transmission through sea ice/melt ponds, heat and freshwater convection and under-ice melt pond formation.

SHEBA observations showed that, during the melt season, the combined energy transmitted through bare ice and melt ponds was equivalent to that through leads, leading to the interior and bottom ablation of sea ice and the warming in upper ocean (Perovich, 2005). Within the sea ice-melt pond mosaics, transmission of short-wave irradiance through melt ponds (40-70\%) is typically $\sim 4-5$ times higher than that through the white ice (5-15\%) and the maximum and minimum transmissions are just below the center of the melt pond and below the bare ice, respectively
(Inoue and others, 2008b; Ehn and others, 2011; Frey and others, 2011). Therefore, the light transmittance varies not only as a function of surface type (melt ponds or white ice), areal fraction and ice thickness (Nicolaus and others, 2012; Katlein and others, 2015) but also in relation to melt pond size and shape, and their spatial distribution (Ehn and others, 2011; Frey and others, 2011). This is the reason why the visible light transmittance under bare ice does not obey the exponential decay with depth, but has a peak at depths of $5-10 \mathrm{~m}$ below the bottom side of sea ice (Frey and others, 2011). Katlein and others (2015) concluded that sea ice thickness is the most important predictor for light transmission on large scale $\left(>1000 \mathrm{~m}^{2}\right)$, while surface properties such as melt ponds dominate the spatial distribution of the under-ice light field on smaller scale. This scale division is believed to come from the typical size range of melt ponds. The horizontally heterogeneous sea ice surface may impact the light field in the upper ocean under the melting sea ice, where massive phytoplankton blooms take place (Mundy and others, 2009; Arrigo and others, 2012; Palmer and others, 2014).

Moreover, at the advanced stage of melt, massive surface meltwater penetrates down into and through the sea ice due to percolation drainage. This convective overturning and flushing (freshening) causes significant disturbance to the nutrient replenishment and space availability for algal biomass (Mundy and others, 2007, 2011). Thus, the extent and distribution of these freshwater interlayers and false bottoms would be expected to be in close relation to the distribution of melt pond size and shape. Therefore, the abundance and size distribution of melt ponds is critical to assessing the role of ponds in these regional and global scale biogeochemical processes. How many melt ponds are there and how big are they? This is one of the most fundamental questions when assessing the roles of ponds in regional and global biogeochemical cycling (Arrigo and others, 2012; Vancoppenolle and others, 2013). Air- and ship-based photography can provide sub-meter spatial resolution, and is conventionally used to characterize the melt pond size and number/abundance at a regional scale (Tschudi and others, 2001; Perovich and others, 2002b; Lu and others, 2011).

Chinese Research Expedition to Arctic in summer 2010 (CHINARE2010) conducted a comprehensive field campaign on sea ice conditions from marginal ice zone to central Arctic, especially over the regions north of $88^{\circ} \mathrm{N}$ where no satellite sensors cover. This paper presents the melt pond coverage, size distribution and surface geometry (i.e. pond boundary geometry) derived from the aerial photography of the cruise. Our goals are (1) to characterize ice surface geomorphology and melt pond size-abundance distribution; (2) to quantitatively represent the melt pond shape and generalize representative pond geometries; (3) to conceptually evaluate the effects of pond size and geometries on pond evolution and transmitted radiation field within under-ice ocean water.

\section{DATA ACQUISITION AND PROCESSING}

\section{General ice conditions}

A continuous zone of low ice concentration ( $250-70 \%)$ was observed by satellite in August of 2010 across the central Arctic basin (Fig. 1), even connecting the Pacific Arctic Sector (PAS) and the Atlantic Arctic sector (http://nsidc.org/ arcticseaicenews/). Coincidently, CHINARE2010 conducted 

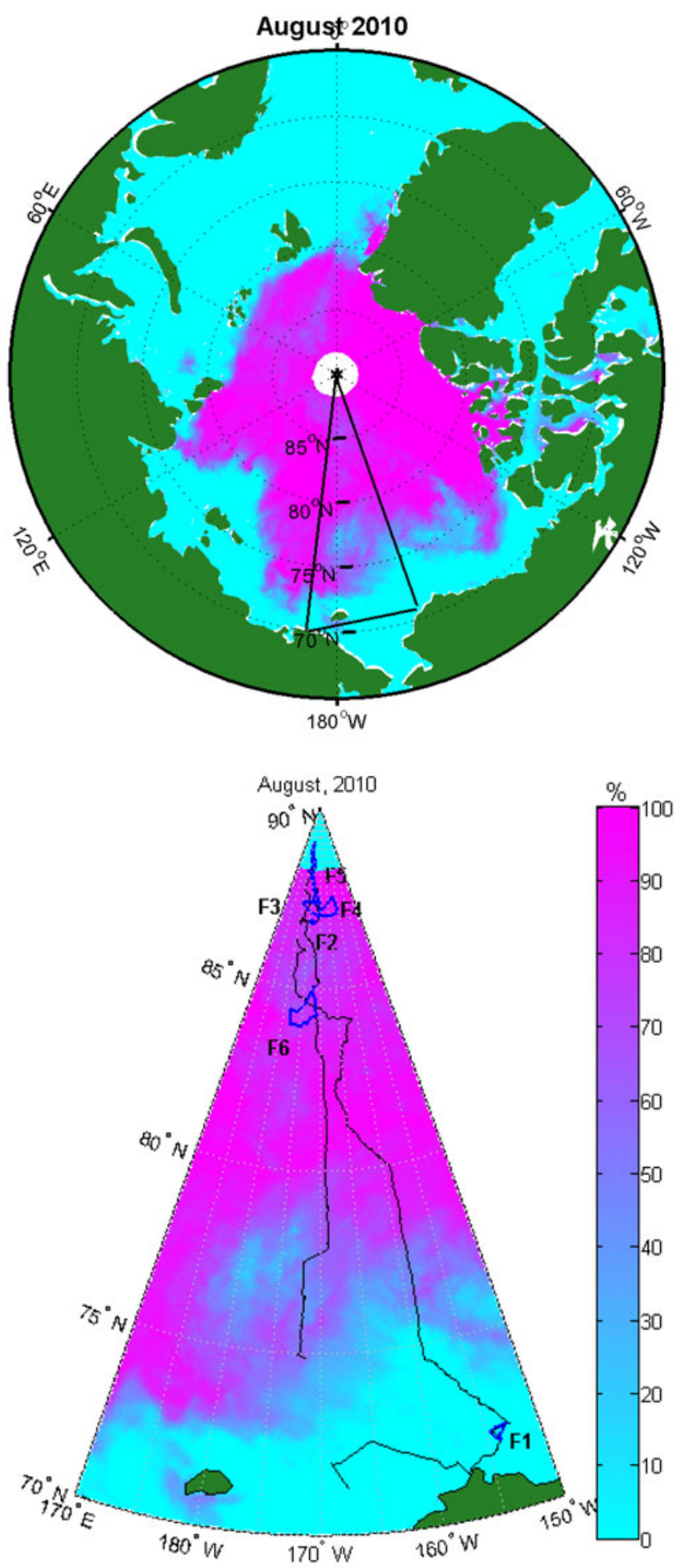

Fig. 1. The August-averaged sea ice concentration (top) with the black triangle denoting the observing regions during the CHINARE2010 (bottom). The thin black and blue lines denote the R/V Xuelong cruise track and six helicopter flight trajectories, respectively.

a comprehensive field campaign on atmosphere-ice/ocean interactions and the responses of the marine ecosystem to climate change in high PAS using the icebreaker R/V Xuelong and a helicopter onboard. The underway shipand helicopter-based ice observations were primarily in the Chukchi Sea, Beaufort Sea, Canada Basin and Central Arctic Ocean. Ship-based ice observations were conducted to record the principal information on ice concentration, floe size, ice type, melt pond coverage and ice and snow thickness (Xie and others, 2013). A Geonics EM31ICE $(9.8 \mathrm{kHz})$ was mounted off the port side to measure the ice and snow thickness within pack ice zones (Wang and others, 2012). Eight short-term (3-4 h each) and one $12 \mathrm{~d}$ ice stations were performed during the cruise with detailed snow, ice and pond physical and optical properties measured and sampled (Huang and others, 2011, 2013; Lei and others, 2012; Xia and others, 2015). The second EM31 instrument $(9.8 \mathrm{kHz})$ was deployed for snow and ice thickness profiles in each station. For detailed information on the field investigations, please see Xie and others (2013). In total, six helicopter flights with photographic surveys were conducted along the research cruise. Five flights (i.e. F2F6) were performed in the central Arctic Ocean to extand the surface-based measurements during the ice camp period (7-19 August 2010), while one flight (i.e. F1) was located in marginal ice zones (Fig. 1).

During the cruise, a rapid retreat of PAS sea ice was witnessed by the R/V Xuelong, which entered the ice zone at $71.9^{\circ} \mathrm{N}, 168.8^{\circ} \mathrm{W}$ on 24 July, and came back out at $75.5^{\circ} \mathrm{N}$, $172.2^{\circ} \mathrm{W}$ on 29 August. During the entire cruise period, ice was in a stage of rapid melting and retreating, while some precipitation (rainfall) events modified the melt. The averaged ice thicknesses were lower than $130 \mathrm{~cm}$ based on ice watch and EM31 instruments. AMSR-E/ASI sea ice concentration products (Fig. 1) show that a distinct unusual transpolar reduction of sea ice lasted from the beginning to the late of August. The ice convergence and divergence caused by a concurrently extensive low pressure system and bottom melt due to higher ocean heat flux were believed to account for this reduction (Kawaguchi and others, 2012).

\section{Aerial photography}

To conduct the aerial surveys, a rigid plastic box was mounted outside the helicopter in a downward-looking orientation. This box contained a Canon G9 camera (with a resolution of $3264 \times 2248$ pixels), a portable GPS and a pressure differential altimeter. A data cable was used to connect the camera to a laptop computer aboard the helicopter. The computer controlled the camera for photographing once every $6 \mathrm{~s}$ and also recorded the pictures as a data logger. The flight altitude varied according to the weather conditions, but was generally between 150 and $500 \mathrm{~m}$. Each photo covered an area between $147 \mathrm{~m} \times 100 \mathrm{~m}$ and $490 \mathrm{~m} \times 335 \mathrm{~m}$, yielding the mean resolution of $0.10 \mathrm{~m}$ per pixel at $300 \mathrm{~m}$ height. The images were spaced without overlapping, with each picture representing an independent zone. The total time and distance for all flights was 1193 min and $1450 \mathrm{~km}$, respectively. Of the 5624 images collected, only $3.9 \%$ could not be processed due to the poor contrast resulted from low clouds or fog contamination. The images mainly covered $72.0^{\circ} \mathrm{N}-89.0^{\circ} \mathrm{N}$ and $153.0^{\circ} \mathrm{W}-$ $180.0^{\circ} \mathrm{W}$, located in the high Arctic, except for the flight F1 (near the Alaskan coast region) (Fig. 1). Table 1 summarizes the information for all survey flights. Aerial images provided a large-scale perspective for small features such as small leads, ridges and melt ponds near the North Pole, where satellite remote sensing usually cannot cover.

\section{Image processing}

Several algorithms can be found in the previous studies to distinguish surface types from images of Arctic sea ice. For 
Table 1. The survey flights information

\begin{tabular}{|c|c|c|c|c|}
\hline $\begin{array}{l}\text { Flight } \\
\text { no. }\end{array}$ & Date UTC & $\begin{array}{l}\text { Altitude } \\
\text { m }\end{array}$ & $\begin{array}{l}\text { Number } \\
\text { of images }\end{array}$ & Area range \\
\hline F1 & 26 July & 167 & 599 & $\begin{array}{l}71.9 \sim 72.4^{\circ} \mathrm{N} \\
152.8 \sim 154.6^{\circ} \mathrm{W}\end{array}$ \\
\hline F2 & 13 August & 100 & 630 & $\begin{array}{l}86.8 \sim 86.9^{\circ} \mathrm{N} \\
172.5 \sim 175.0^{\circ} \mathrm{W}\end{array}$ \\
\hline F3 & 16 August & 257 & 861 & $\begin{array}{l}86.9 \sim 87.5^{\circ} \mathrm{N} \\
168.0 \sim 180.0^{\circ} \mathrm{W}\end{array}$ \\
\hline F4 & 17 August & 184 & 851 & $\begin{array}{l}86.9 \sim 87.6^{\circ} \mathrm{N} \\
160.0 \sim 172.0^{\circ} \mathrm{W}\end{array}$ \\
\hline F5 & 19 August & 430 & 1416 & $\begin{array}{l}87.0 \sim 89.5^{\circ} \mathrm{N} \\
171.0 \sim 180.0^{\circ} \mathrm{W}\end{array}$ \\
\hline F6 & 22 August & 65 & 1267 & $\begin{array}{l}83.8 \sim 85.2^{\circ} \mathrm{N} \\
170.0 \sim 179.0^{\circ} \mathrm{W}\end{array}$ \\
\hline
\end{tabular}

example, Pedersen and others (2009) applied a neural network to retrieve the fractions of snow-covered ice, bare ice, brash ice and open water in a continuous series of photographs. Sankelo and others (2010) applied an iterative image classification method to distinguish melt pond from surrounding snow and ice on the images obtained by an obliquelooking camera installed on the drifting polar schooner Tara. Renner and others (2013) presented a semi-automatic classification algorithm, which is based on discriminant analysis of spectral and textural features in normalized images using a training set and includes five ice classes: open water, thin ice, bare ice, melt ponds and submerged ice. Webster and others (2015) developed an algorithm to classify the satellite imagery in grayscale into sea ice, thin ice, melt pond and open water classes on two contrasting ice types: first-year and multiyear sea ice. Miao and others (2015) provided an object-based classification algorithm to automatically extract sea ice and melt ponds from aerial photographs.

In this study, our aim is not the development of new algorithm or the inter-comparisons among different methods. Therefore, a traditional method that has frequently employed in previous studies (Perovich and others, 2002b; Inoue and others, 2008a; Lu and others, 2010, 2011; Krumpen and others, 2011) is selected to process the images. The sea ice images acquired by aerial photography are segmented into three different categories: snow-covered or bared ice, melt ponds and open leads, based on the color difference of ice surface features (e.g. Fig. 2). Partitioning an image into the three categories is executed by manually selecting red, green and blue (RGB) thresholds based on color distribution histograms of each image independently (Weissling and others, 2009). This method is time-consuming because the human intervention is required for each image, but has been proved to suitable for different kinds of ocean surface condition in Arctic in different studies (e.g. Lu and others, 2010). Therefore, it is still being widely employed as dealing with sea ice images with large variability especially in summer Arctic.

As with previous studies using the same method (e.g. Krumpen and others, 2011), submerged ice (resulting from lateral melting) presented at some ice floe edges are classified as melt ponds and melt holes (i.e. melt ponds that penetrated through the underlying sea ice cover) are classified as leads in this study. It is partly because of the similar optical and physical properties between submerged ice and pond, and between hole and lead, respectively (Inoue and others, 2008a). Although sophisticated algorithms (e.g. Renner and others, 2013; Miao and others, 2015) could distinguish these features, our method still treats them as pond and water, respectively. On the other hand, an additional category would largely increase the complexity of image processing, and the fractions of these features are very small compared with the melt ponds and image coverage, so the resultant errors in the mean value of pond statistics for one image are likely to be small (Perovich and others, 2002b). In addition, visual inspections of melt ponds on images reveal that the identified blue objects smaller than this threshold (i.e., 100 pixels in this paper) are actually not real melt ponds, and the probability of false melt pond increases as the objects get smaller. By discounting objects of $<100$ pixels, this problem is minimized. At an altitude of $100 \mathrm{~m}$, the image resolution of $3264 \times 2248$ pixels indicates that a 100-pixel object has an area of $\sim 0.1 \mathrm{~m}^{2}$, and an equivalent diameter of $0.3 \mathrm{~m}$.

The areal fraction of different surface categories: $A_{\mathrm{si}}$ for ice/snow, $A_{\mathrm{p}}$ for melt pond and $A_{\mathrm{w}}$ for open water, can then be determined according to the results of classification (Fig. 2b). Knowing area fractions is sufficient for crudely estimating regional averages of albedo and of surface ablation. However, statistics on pond size and shape distributions are needed to understand and model the properties and evolution of melt ponds (Perovich and others, 2002b). For instance, the area, and the perimeter of individual melt ponds influence the solar and heat energy partitioning within ponds and surrounding ice, thus impacting the ice ablation and melt pond evolution (Skyllingstad and Paulson, 2007; Ehn and others, 2011).

The geometric parameters are extracted from individual melt ponds that have a complete boundary within the coverage of one image. Blue objects (i.e. individual ponds or nested ponds) that cross the boundary of an image are excluded from the statistics (Fig. 2c) owing to their incomplete information presented in the image. Each of these separate blue objects is identified from the background to calculate its geometry. Because the sizes of melt ponds are always less than the image coverage, exclusion of incomplete ponds only reduces the amount of melt ponds in geometry calculation, but does not affect the mean of pond geometry from a statistical point of view (Perovich and others, 2002b). This is contrast to the analyses of floe size from aerial photography (Toyota and others, 2011), in which large floes always have a bigger size than the image coverage, so the truncation error due to the limited image coverage must be considered in the statistics of floe geometry (Lu and others, 2008).

The basic parameters of a melt pond include pond area $(S)$, perimeter $(P)$, fractal dimension $(D)$ and mean caliper diameter (MCD, denoted $L$ ). The fractal dimension $D$ is an indicator of the complexity and self-similarity of the pond shorelines, and can be determined by the so-called yardstick and box-counting methods. It falls in the interval $(1,2)$ for an arbitrary curve in plain, and is usually used to characterize the size distributions of inland lakes (Seekell and Pace, 2011; Seekell and others, 2013), and also Arctic melt ponds tentatively (Hohenegger and others, 2012). The MCD $(L)$ is defined as the caliper dimension (namely the distance between two parallel lines that are tangent to the pond's shorelines) obtained by averaging over all directions. For a circle, the MCD simply equals to the diameter; for a square, MCD is the intermediate between the length of a side and the 

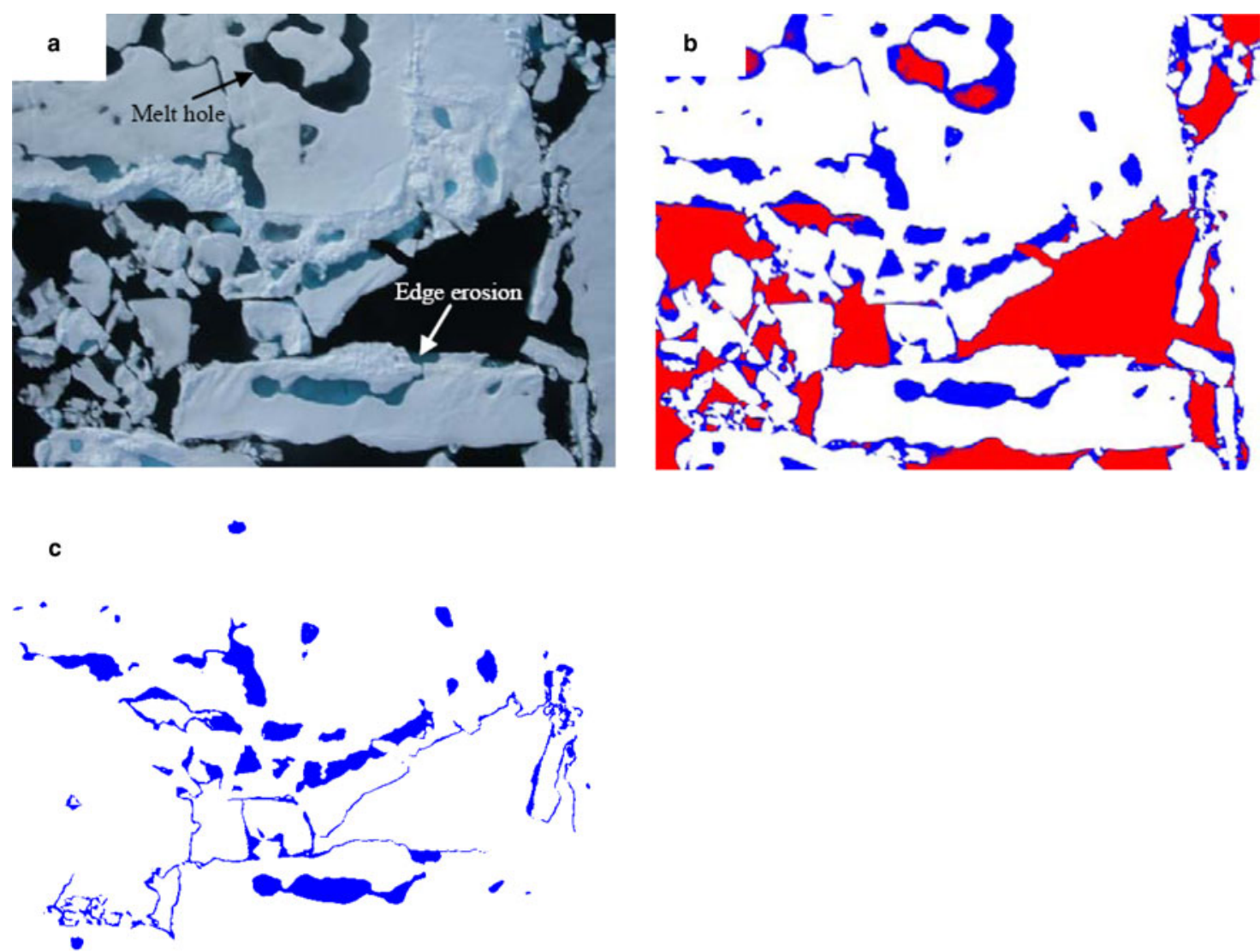

Fig. 2. An original aerial image (a) was processed into a tricolor classes (b), on which white is for snow-covered/bare ice, blue for melt ponds and red for open water; and (c) blue melt ponds were identified from the background, with individual melt ponds remained after excluding those touching the image boundary.

diagonal. Some secondary parameters can be calculated, such as the roundness $R=P^{2} /(4 \pi S)$, the ratio of perimeter to area $P / S$ (similar to the ratio of sidewall area to bottom area introduced by Skyllingstad and others (2007)) and the convex degree $C=P / L$, which is actually a descriptor of convex pond shape (Lu and others, 2008). The roundness $R$ has a minimum value of 1 for an absolutely circle, 1.273 for a square, or a bigger value for more intricate shapes. Convex degree $C$ is equal to $\pi$ for any convex shape, a small concavity adds perimeter without changing MCD, increasing the ratio $P / L$. Physically, for a given areal fraction of melt pond, the more convex ponds of smaller area there are, the longer their total perimeter is, which increases the contact area of melt ponds with the associated sea ice.

\section{RESULTS}

The general ice conditions at different locations can be qualitatively estimated from visual inspection of the aerial images. Overall, when the first flight was conducted on 26 July, the sea ice was undergoing an advanced summer melting phase, in which the rotten ice floes were almost fragmentized, melt ponds melted to penetrate the underlying ice cover or were interconnected into large, complex networks and the meltwater ran to the ice boundary, connecting to the underlying ocean. When the later flights flew over the high latitude Arctic, some melt ponds and leads started to form very thin ice layers, but they usually had distinct appearances compared with surrounding ice/snow unless thick snow accumulated on top of the thin ice layer. The natural melt ponds formed distinct shapes and were seen spreading over the ice surface. Some even merged with adjacent ones into long ditches and created complicated networks, but generally not as complex as those detected during flight $\mathrm{F} 1$ and not melted through. Ice ridges, cracks and open leads, resulting from floe collision and compression events during ice drifting and/or wave propagation were widely seen. This produced more floes and brash ice with much smaller size and resulted in an increase in the possibility for a decline of ice concentration in the central Arctic basin.

\section{Areal fractions}

Areal fractions of different classes are the first direct results from aerial image processing. Overall it shows a large spatial variability along the path of each flight and between flights (Fig. 3). Flight F1 was a short distance within the marginal ice zone (MIZ), where quantities of separated rotten ice floes and cakes were spread over the open water surface. Melt ponds were connected into pond networks and mostly had penetrated through underlying ice. So the area fraction of open water along the $\mathrm{F} 1$ track was very high with a mean of $61.8 \%$, and the $A_{\mathrm{si}}$, and $A_{\mathrm{p}}$ were respectively $27.0 \%$ and $11.2 \%$. For the other flights over high latitudes, the ice fraction increased dramatically. The water fraction fluctuated within a large range for any single photo, from $0 \%$ to almost $100 \%$, indicating the presence of adjoining open water and ice floes.

The mean values of areal fractions for a flight are the quantities of prime interest for extrapolating from the local scale, and for doing discrete element modeling or single column modeling. Figure 3 also includes the fraction of the ice that is covered by ponds (i.e. ponded, $A_{\mathrm{pi}}=A_{\mathrm{p}} /\left(A_{\mathrm{si}}+A_{\mathrm{p}}\right)$ ). This 


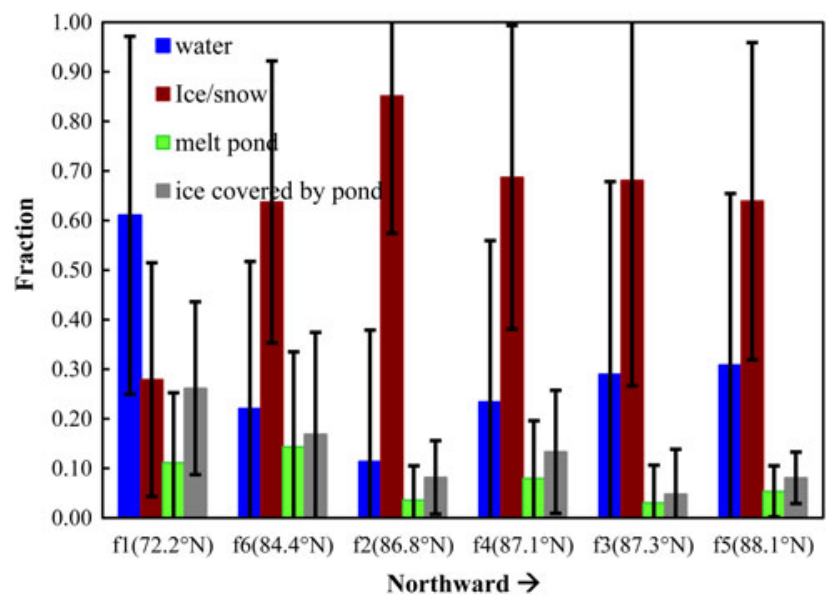

Fig. 3. The averaged area fractions and standard deviations of the three calsses $\left(A_{\mathrm{si}}, A_{\mathrm{p}}\right.$ and $\left.A_{\mathrm{w}}\right)$ and pond coverage $\left(A_{\mathrm{p}}{ }^{*}\right)$, the averaged fraction of the ice area covered by ponds, of each flight. The flight sequences are adjusted according to their averaged latitudes (the values in brackets).

adjusted fraction is to account for changes due to variations in ice concentration. Although there are great deviations of fractions within each flight, the sea ice fractions over high latitudes (F2 to F6) are much greater than those in low latitude (F1). Numerous leads presented within high Arctic north of F6 $\left(\sim 85^{\circ} \mathrm{N}\right)$ account for the mean water fraction of $23.2 \%$, with a maximum of $30.7 \%$. This supports the low ice concentration in these regions ( $60-75 \%)$ observed by AMSR-E/ASI products provided by the University of Bremen (Fig. 1), indicating a good availability of AMSR-E/ASI for retrieving the general sea ice conditions. However, the fraction of melt pond and ice covered by ponds show a general trend of decreasing northwardly, which is consistent with Lu and others (2011). Melt pond area and fraction are controlled by numerous processes: the ice/snow topography, the ice types (FYI and MYI), the lateral and bottom melting/refreezing and their duration, the solar irradiation partitioning and the permeability of ambient and underlying sea ice and even ice floe dynamics (Eicken and others, 2002, 2004; Polashenski and others, 2012). During the later flights, the high latitudes started to refreeze and the melt season was shorter and the refreezing was earlier farther northward. The shorter melt season and earlier refreezing are the predominant reasons for the lower pond fraction in higher latitudes.

\section{Pond size}

Approximately $15-20 \%$ of images are selected stochastically for statistics along each flight path. Results indicate that ponds are abundant in number and diverse in size along each flight path (Fig. 4). It is noted that three parameters showed similar variation trend along latitude, revealing a good correlation between them. Thus, only the distribution of pond area is discussed later. Median values of pond size are obviously lower than the means, in agreement with previous findings (Yackel and others, 2000; Tschudi and others, 2001; Perovich and others, 2002b), implying a large abundance of relatively small ponds over the observed regions (Miao and others, 2015). Interestingly, the melt pond sizes seemed to show an unexpected latitudinal trend of increasing. In fact, some processes might account for this. First, flight F1 actually flew over ice floes that were likely to be imported from broken fast-ice from Alaskan bank or Canadian Archipelago, inferred from the presence of sediment on their surface (Eicken and others, 2005; Darby and others, 2011). These small floes were the result of fragmentation and deterioration of original large and thick first year and multiyear ice floes, and were not able to hold melt ponds of large size due to lateral drainage and melting through although the melt pond fraction was the largest (Fig. 3). Second, flights F2 and F6 flew over lower latitudes than flights F3, F4 and F5, thus longer time of melt elapsed for areas under the F2 and F6 footprints, probably leading to the horizontal drainage and vertical percolation of meltwater. Third, the flight altitude difference could have an effect. The altitudes of flights F3, F4 and F5 were overall much higher than others, especially the F3 and F5 (Table 1). A single image therefore covers a much larger area, which increases the chance of larger melt ponds falling entirely into the image (Perovich and others, 2002b). Further, the floe dynamical history (collision or disintegration), ice types (MYI or FYI) and pond water flushing and penetrating, also have an impact on the individual pond area. For instance, caused by collision or floe breaking up, ponds can be flushed and drain into ocean, thus the freeboards of drained floes become positive, enhancing the pond water penetrating, consequently decreasing the overall melt pond fraction within a very short time.

The pond size/area distribution histograms (Fig. 5) show that small ponds predominate the number of ponds, as illustrated by the differences between their median and mean sizes (Fig. 4). The pond size distributions are of a similar pattern for all flights with respect to both area and perimeter. This is consistent with previous observations during SHEBA, FIRE and other field projects (Barber and Yackel, 1999; Yackel and others, 2000; Tschudi and others, 2001; Perovich and others, 2002b).

To compare the pond statistics in different locations, a curve fitting process was applied to the data. A power-law function, usually employed to quantify the inland lake size distribution (Seekell and Pace, 2011; Seekell and others, 2013; Zhang and others, 2014), well fitted the probability density $f(S)$ as a function of pond area $S$ as:

$$
f(S)=a S^{-b}
$$

where $a$ and $b$ are coefficients to be determined and varied from flight to flight (Table 2). Most correlation coefficients $\left(R^{2}\right)$ are greater than 0.9 at a significance level of $95 \%$, arguing for a nice relationship. Perovich and others (2002b) expected that the values of pond statistics would vary by season and location, but that the overall trends would not change. Table 2 shows the intercepts (a) with large variation, but minor deviation $(1.45 \pm 13 \%)$ with slopes $(b)$. This result suggests the linear correlation (actually power law) is acceptable, supporting Perovich and others (2002b)'s judgment.

\section{Pond shape}

Pond shape parameters, including the roundness $(\mathrm{R})$, fractal dimension (D), convex degree $(C)$ and the ratio of perimeter length to area $(P / S)$, computed from isolated ponds, are illustrated in Figure 6 for each flight.

The fractal dimension of pond boundary $(D=1.09 \pm 0.04$ with median $=1.07$ ) seems rather uniform, implying a certain similarity of melt ponds at varied locations and evolution 

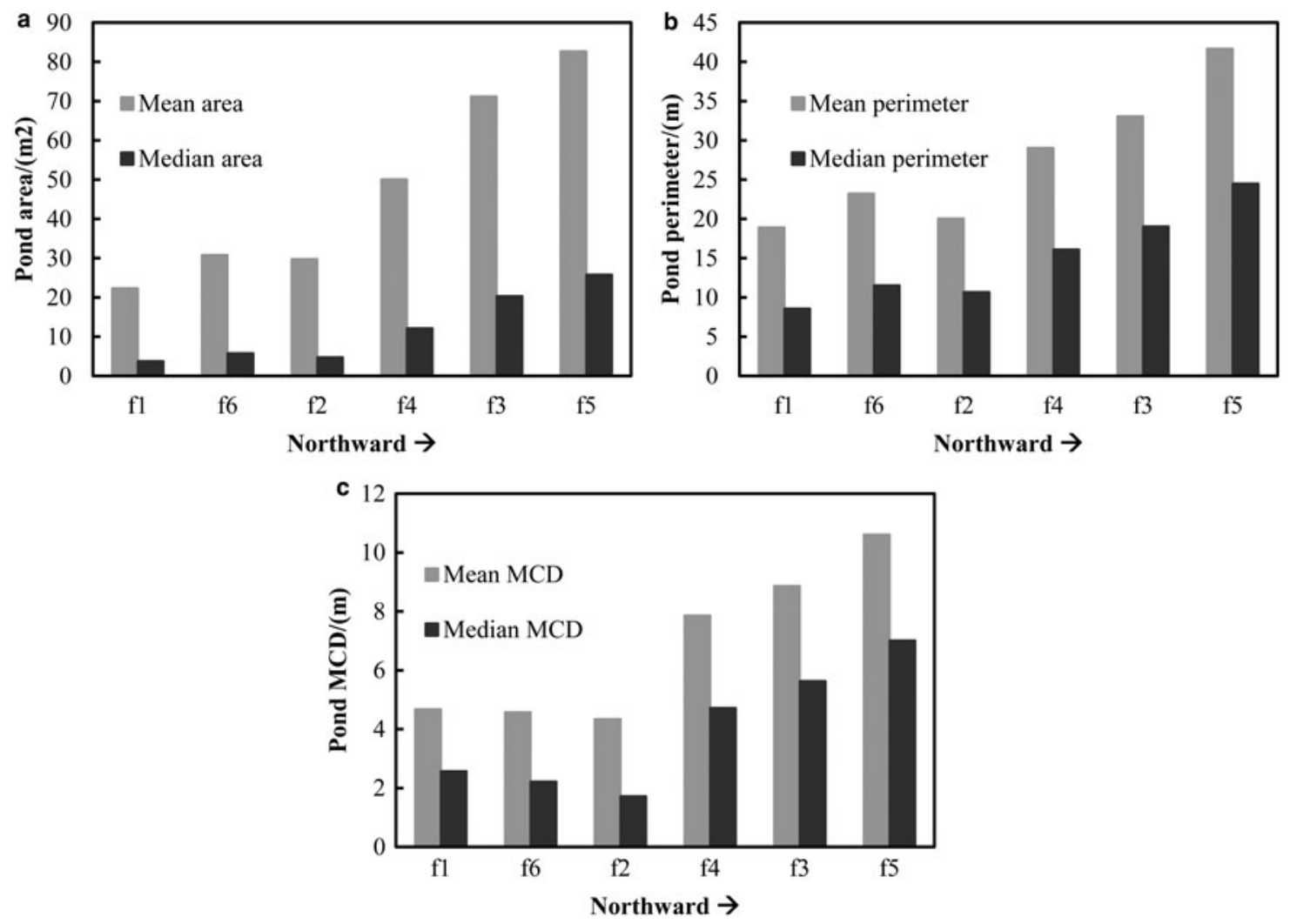

Fig. 4. Statistical description of melt pond size for each flight: (a) area, (b) perimeter and (c) mean caliper diameter (MCD). The sequence of flight was adjusted in northward direction. Standard deviation of each parameter is not plotted due to their large values compared with the corresponding means.

stages. The convex degree considerably deviates from the value for convex shapes $(\pi)$ with a large standard deviation (STD), reflecting that the pond shoreline had many concavities and was quite serrated. The ratio of $P / S$ shows the largest differences between flights, actually indicating the differences in number density of small ponds, because this ratio value is somewhat inversely proportional to the pond diameter $d$ (equivalent to MCD) if the pond can be regarded as a circle with a perimeter $P=\pi d$ and an area $S=\pi d^{2} / 4$, thus $P / S=4 /(\pi d)$. The mean roundness for ponds ranges from

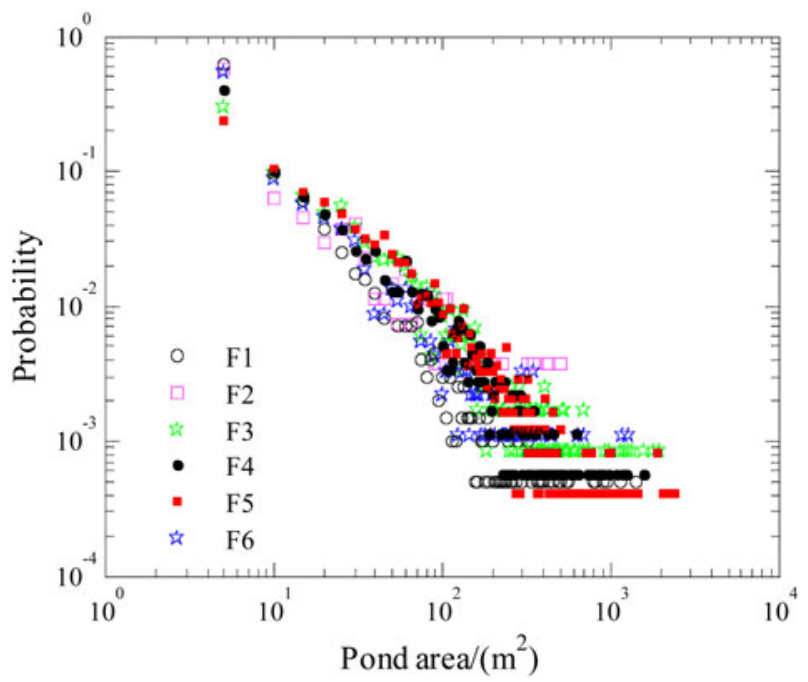

Fig. 5. Melt pond area distribution for each flight, with an area bin of $5 \mathrm{~m}^{2}$.
1.9 to 2.9 at varying locations. For simple comparison, rectangles having an aspect ratio of $1: 4$ and $1: 17$ have a roundness of $\sim 2.0$ and 2.9, respectively. Therefore, the roundness values (Fig. 6a) indicate dominant ponds in August were not round, i.e. in the later stage of pond development, especially those seen in the F2 and F4. In addition, all of these values reaffirm the presence of many geometrically complex ponds on later summer of Arctic sea ice, in good accordance with previous observations (Perovich and others, 2002b; Lu and others, 2011).

Figure 7 shows pond geometry as a function of pond area. Despite significant deviations, there are generally positive trends of roundness and convex degree, a negative trend of the ratio $P / S$, and no relationship between the fractal dimension and pond area. An increment in roundness and convex shape implies that the pond shoreline would become more enlongated and more convoluted (such as more zigzag in pond border line) as pond area increases. This is consisitent with the decrease in $P / S$ ratio, indicating the pond border becoming more serrated as the pond area increases.

\section{DISCUSSIONS}

In order to quantify the melt pond size/shape and abundance at a regional or global scale, high-resolution (meters and even sub-meter) satellite SAR is a promising approach, such as ERS-1/2, RARDARSAT 1/2, Envisat ASAR and TerraSAR X. Based on the intercomparisons of helicopterborne SAR, aerial observations and TerraSAR X, Kim and others (2013) concluded that the size distribution (also a power-law function) and shape (roundness) of melt ponds derived from high-resolution SAR could provide a level of 
Table 2. Curve fitting results of pond area distribution to power law

\begin{tabular}{lllllll}
\hline & F1 & F2 & F3 & F4 & F5 & F6 \\
\hline$a$ & 8.121 & 1.411 & 3.950 & 4.486 & 4.781 & 4.108 \\
$b$ & 1.762 & 1.174 & 1.392 & 1.456 & 1.421 & 0.9153 \\
$R^{2}$ & 0.9529 & 0.8864 & 0.9116 & 0.9148 & 0.9300 \\
\hline
\end{tabular}

detail and accuracy comparable with those obtained from aerial photographs, but SAR (especially spaceborne TerraSAR $X)$ underestimates the melt pond fraction and number density of small ponds to some degrees depending on their resolution. Since the power-law function is regarded extensively as the best equation simulating the melt pond size-number relationship, the abundance and surface area of small, unrecorded ponds by SAR images can be estimated based on extrapolation from power-law size distributions, similar to the approach applied frequently in lake research (Downing and others, 2006; Seekell and others, 2013), offsetting the resolution inadequacy of spaceborne SARs. However, it is still a hard task to retrieve melt pond fraction and number from SAR images at larger scale. There is no solid SAR-based product to be compared with our aerial data.

\section{Melt pond size and shape evolution}

Many processes control the development of melt ponds. Considered as a hydraulic unit, a melt pond can be presented as a surface water body determined by the balance of inflows and outflows, distributed in local depressions. Previous observations concluded that the evolution of melt pond is characterized by four distinct stages, based on the pond behavior and control mechanisms (Eicken and others, 2002; Polashenski and others, 2012).
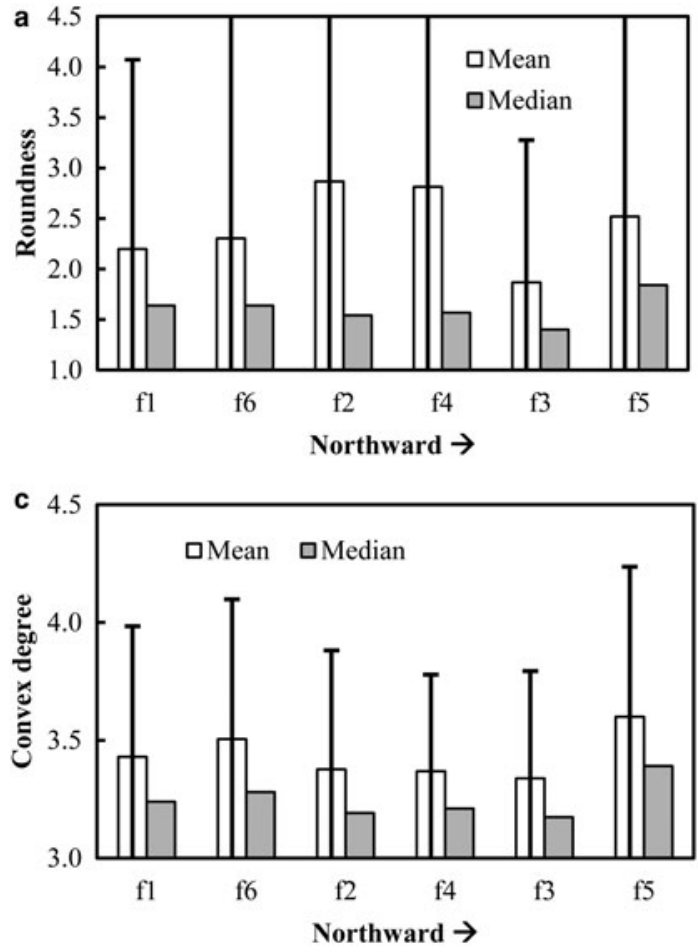

Given the temporal evolution, the mechanisms governing the pond geometry are quite complicated and multiple-factor controlled, such as, ice/snow topography, pond sidewall and bottom ablation, ice permeability, balance between inflows and outflows, and occasionally, precipitation and changing weather conditions. Seeing that understanding melt pond evolution remains a significantly challenging task, a question is whether there are some universal characteristics of pond geometry not depending upon the details of the driving mechanisms. A simplified fractal geometry method is employed here (see Hohenegger and others (2012)). The geometrical features of melt ponds and the complexity of their shorelines can be quantified by the fractal dimension $D_{\mathrm{A}}$ derived from $S \sim P$ data, which are usually used to determine the fractal dimension of lake group, other than the boxcounting method in the section 'Pond shape', defined as

$$
\begin{aligned}
P & =k \sqrt{S}^{D_{A}} \text { with } k>0, \text { then } \\
\log P & =\frac{D_{A}}{2} \log S+\log k,
\end{aligned}
$$

where $P$ and $S$ denote the perimeter and area of a melt pond, respectively. $k$ is a constant. On $\log / \log$ scales, the slope characterizing the $S \sim P$ data is one half of the fractal dimension. The logarithmic area-perimeter data are plotted in Figure 8 for all melt ponds counted in Figure 4. Our analysis
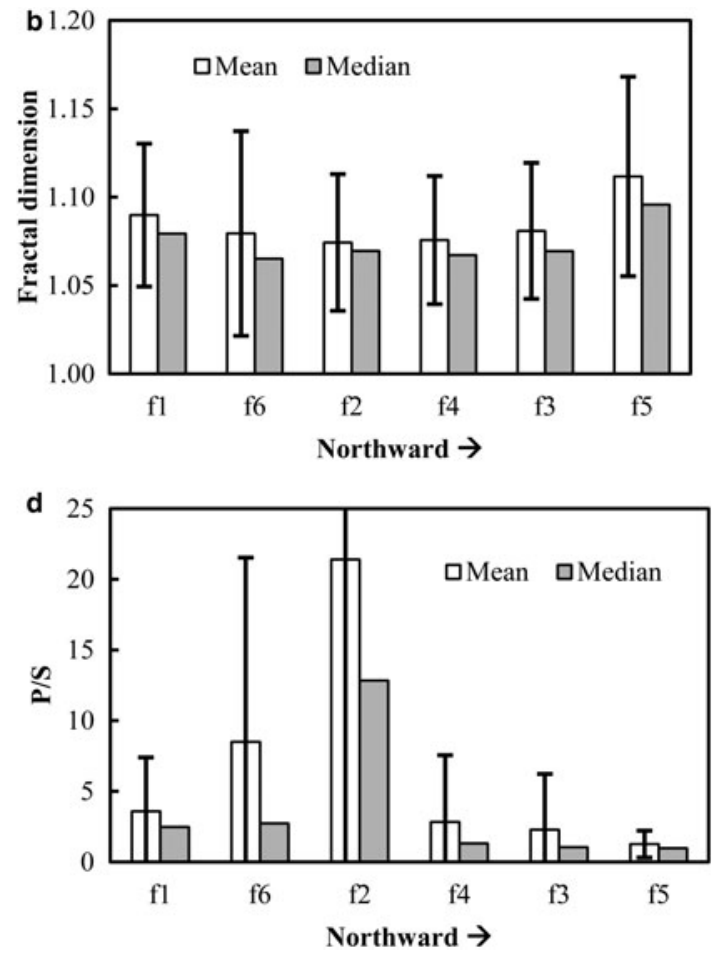

Fig. 6. Statistical description of melt pond shape for each flight: (a) roundness, (b) fractal dimension, (c) convex degree and (d) the ratio of perimeter over area $(P / S)$. 

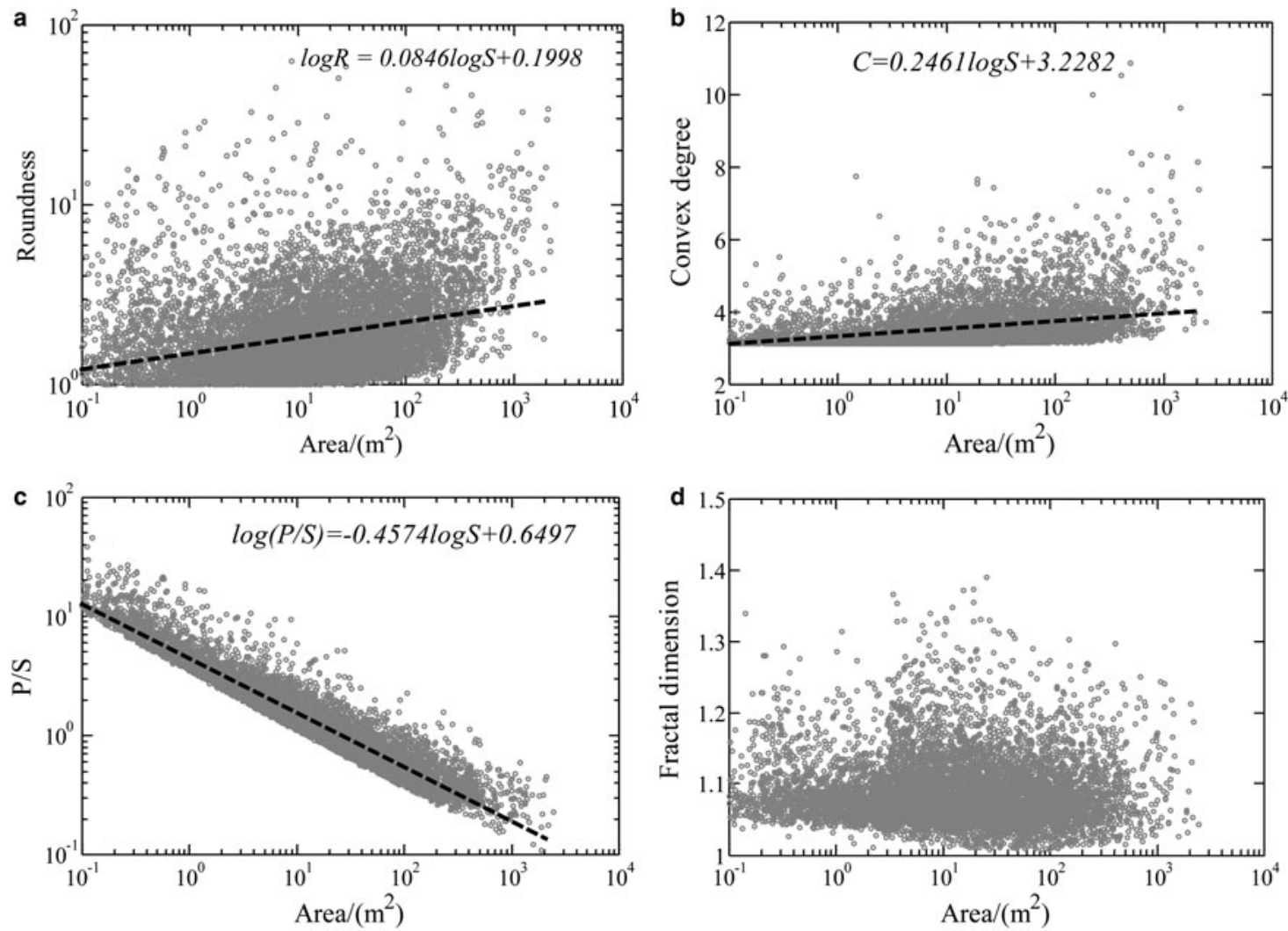

Fig. 7. Pond geometric indicator distribution as a function of pond area: (a) roundness, (b) convex degree, (c) the ratio of perimeter over area $(P / S)$ and $(\mathrm{d})$ fractal dimension of individual pond shoreline. The dotted-lines denote the best linear fitting curves with fitting equations listed correspondingly.

of these data sets indicates that MYI and FYI melt ponds are similar with respect to the perimeter/area relation (i.e. fractal dimension), and both trends change slopes similarly around a critical length scale of $\sim 100 \mathrm{~m}^{2}$ in area, in favorable agreement with findings by Hohenegger and others (2012).

Approximately, at the beginning of melt pond formation (i.e. stage I nominated by Polashenski and others, 2012), shallow ponds emerge on the ice surface, with rather small ponds on MYI but more extensive on FYI. These initial ponds are somewhat circular in shape and their boundaries are simple Euclidean curves with fractal dimension $D_{\mathrm{A}} \approx$ or close to 1 (Fig. 9a). As the melt period progresses, these ponds grow both in area and depth (Morassutti and LeDrew, 1996; Perovich and others, 2003) due to rapid
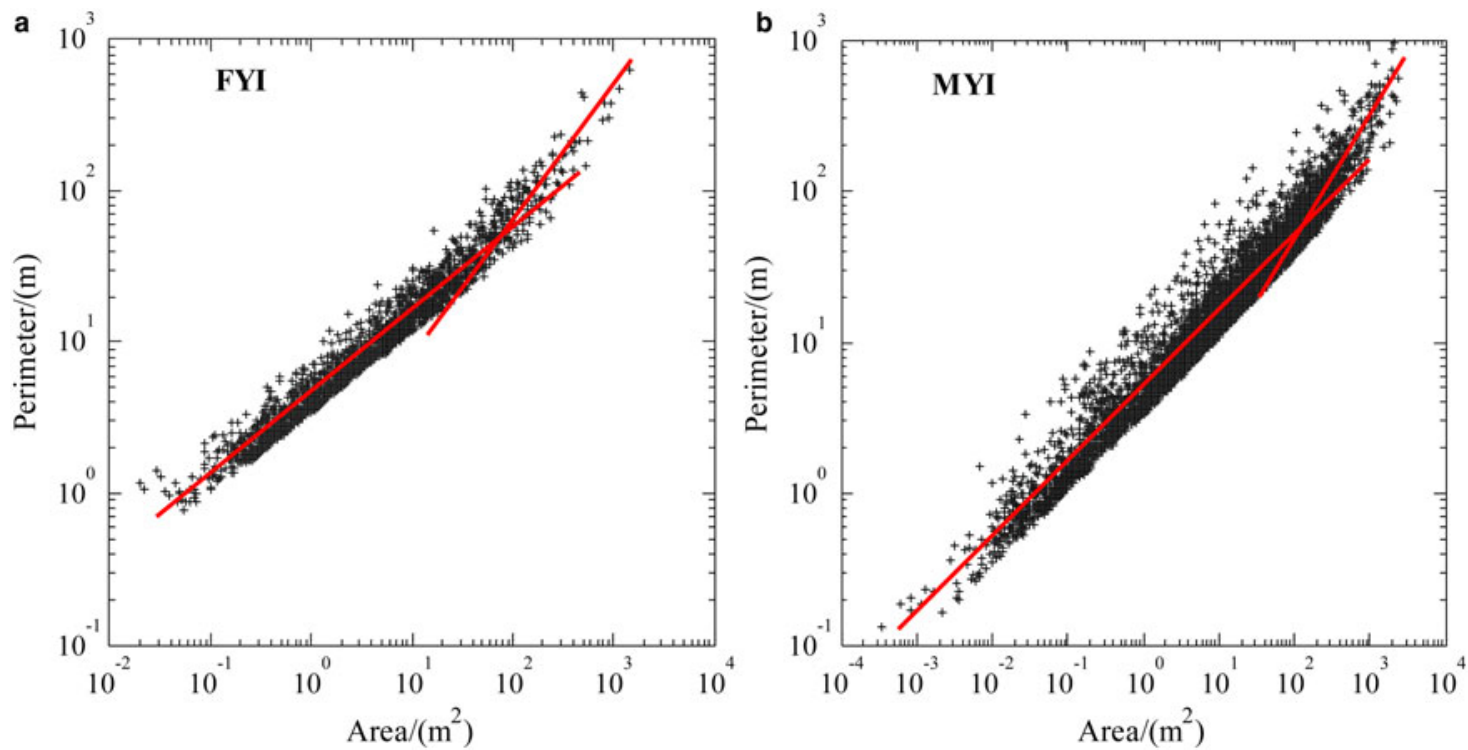

Fig. 8. Area-Perimeter data for melt ponds on FYI (a) and MYI (b) displays a 'bend' around a critical length scale of $100 \mathrm{~m}^{2}$ in area. Red lines indicate the general trends in each subregions. The types (FYI or MYI) of the floes are judged visually and empirically based on their size, color, surface topography (smooth or rough with ridges), location and general ice conditions derived from ship-based ice observations (Xie and others, 2013). 
small simple ponds $\left(A_{p}=3.7 \%, D_{A} \approx 1.0\right)$

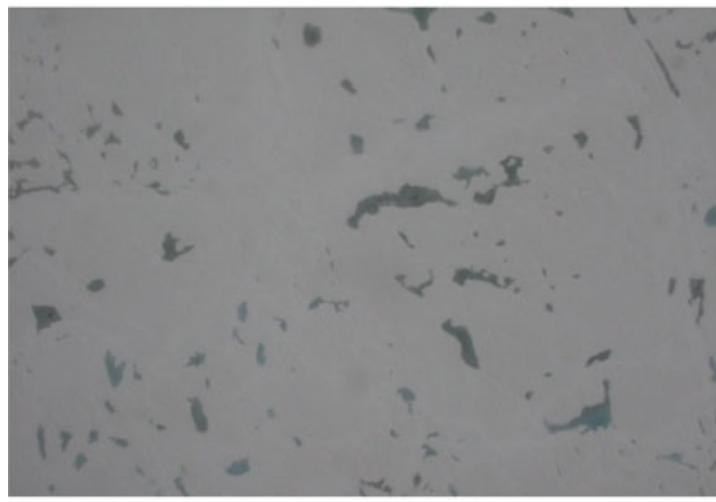

c highly ramified networks $\left(A_{p}=21.1 \%, D_{A} \approx 1.7\right)$

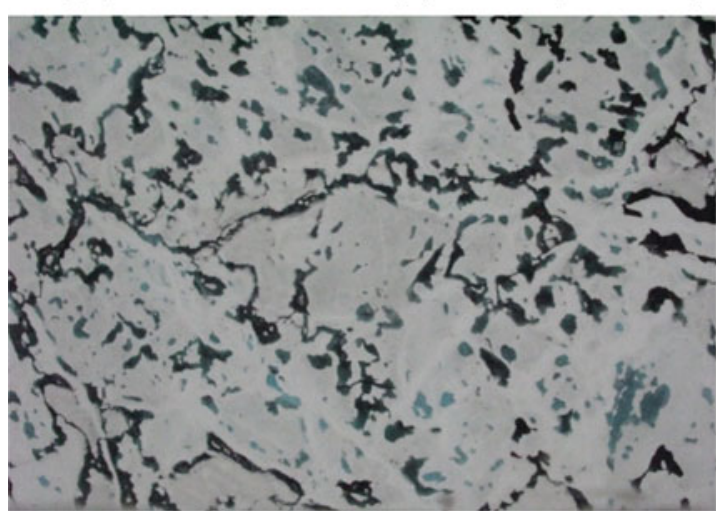

b starting to coalesce $\left(A_{p}=19.7 \%, D_{A} \approx 1.2\right)$

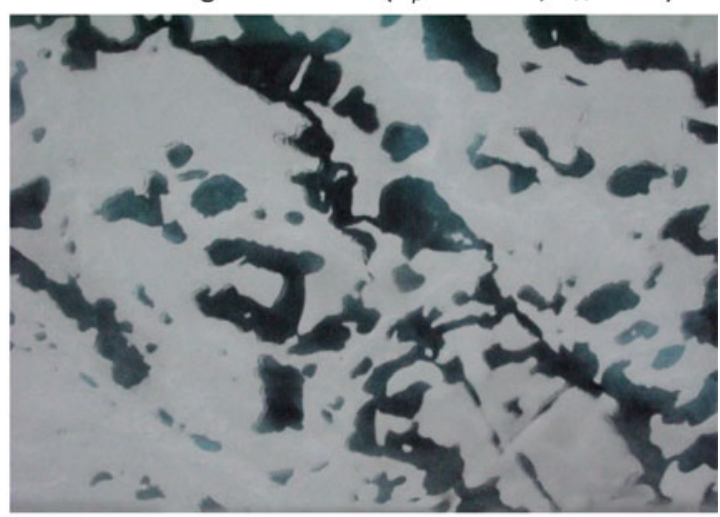

d all ponds melting through $\left(A_{p}=49.1 \%, D_{A} \approx 2.0\right)$

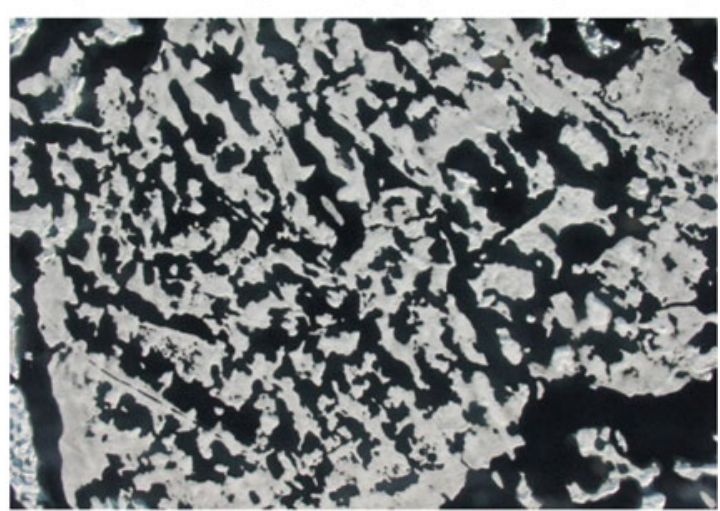

Fig. 9. Evolution of melt pond shape and connectivity. (a) Simple disconnected ponds, (b) ponds extending and starting coalescing to form clusters, (c) mature networks of ponds, (d) dense networks of connected and fully melt-through ponds, the floe would disintegrate by slight wind or flow disturbances. Note that not all shaping stages are expected to take place anywhere. The final stage of pond evolution may vary regionally, and depends on the ice type, latitude and prevailing atmospheric forcing.

meltwater inflows, pond wall and bottom ablation, and limited outflow pathways. As the pond coverage and depth increase, these small isolated ponds may coalesce to form clusters (Fig. 9b), which themselves coalesce to simple and/ or single dendritic ponds (transitional ponds) just spanning the image (Fig. 9c) with $1<D_{\mathrm{A}}<2$, and then fully connected pond networks of much complex shape with $D_{\mathrm{A}} \approx$ or close to 2 (Fig. 9d), most of which actually melt through. During every stage of melt pond evolution (Eicken and others, 2002; Polashenski and others, 2012), pond size and shape vary tremendously in location, melting duration, wind force, floe topography, physics and permeability, from isolated small ponds of regular shape to interconnected networks of complex shape.

These results, with Hohenegger and others (2012), demonstrate that there is a separation of length scales in melt pond structure. Pond complexity increases rapidly through the transition as smaller ponds coalesce to form large connected regions, and may reach a maximum for ponds larger than $1000 \mathrm{~m}^{2}$, whose boundaries resemble spacefilling curves, with $D_{\mathrm{A}} \approx 2$. This scaling separation in pond geometry can ultimately lead to more realistic and efficient treatments of melt ponds and melting processes in climate models. For instance, a scaling separation in the microstructure of an inhomogeneous composite medium (melt pondsea ice) is a necessary condition in numerous homogenization schemes (also known as upscaling) to estimate its overall or effective properties and behaviors, such as floe albedo and light transmission through ponds and its influences on the heat budget of the upper ocean and biological productivity. A large developed ramified pond network, usually spanning an ice floe, is inevitably more effective to contribute to breaking apart a floe than many small isolated ponds.

Moreover, according to the critical length scale for melt ponds, large-scale well-connected pond networks can be considered consisting of small-scale ponds of basic shapes. That is, each melt pond can be broken into basic parts of either thin elongated shapes (called bonds), or approximately convex shapes (called nodes). The structure of a melt pond can be described as a locally dendritic network of nodes joined together through bonds. A simple melt pond with $D_{\mathrm{A}}=1$ is a small network consisting of a single node or possibly a few connected nodes, while more complex melt ponds $\left(1<D_{\mathrm{A}}<2\right)$ are networks consisting of many nodes and bonds. Thus if we assume melt ponds are distributed randomly on the ice floe surface (i.e. homogeneous medium), a universally stochastic model can be proposed for melt pond distribution on the basis of the area-number power-law relationship as shown in Figure 5. This can lead to more realistic and efficient parameterizations for ice floe albedo, radiation transmittance and light field in the upper ocean layer.

\section{Implications for heat transport within pond and heterogeneity of under-ice light field}

During summer, Arctic sea ice is a complicated, changing mosaic of ice/snow, melt ponds and open water. This morphological diversity has considerable impacts on the 
reflection, absorption and transmission of solar energy in iceocean system. The large differences in light reflectance from melt ponds, bare ice/snow, and leads, and the integrated surface albedos, have been well documented by in situ instrumentation, remote sensing technologies and mathematical models. The areal fraction data of sea ice surface types presented in this paper can be used to estimate the albedos of the investigated regions assuming arbitrary values for each surface type. These datasets can also validate and assess recently developed algorithms for retrieving melt pond fraction from air- and space-borne optical sensors (Rösel and others, 2012; Istomina and others, 2014).

Due to more solar energy absorbed by melt ponds, explicitly horizontal and vertical heat transports within ponds, i.e. the heat flux into sidewall for lateral expansion and into bottom for deepening, are needed to be quantified in modeling melt pond evolution, because the bottom and lateral ablation of melt pond is one of the pivotal and durative processes affecting the area and depth of melt pond, hence the surface albedo and vertical radiation through ponds into the underlying ice and ocean (Fig. 10). Typically melt ponds are shallow (depth $<40 \mathrm{~cm}$ ) with salinity $<5$ PSU. Natural convection in the pond rapidly causes mixing that eventually forces an equilibrium temperature with slight wind forces, and even without winds (Skyllingstad and Paulson, 2007; Huang and others, 2011). By using a simple large eddy model with high-resolution turbulence simulation, Skyllingstad and Paulson (2007) argued that the inpond horizontal and vertical current circulations control the horizontal and vertical heat transport into the sidewall and bottom, and determine the significant impacts of pond geometry on pond turbulences and thus on pond growth rates and albedo. The basic ratio $R_{\mathrm{sb}}$ of sidewall area to bottom area could be considered as a combining indicator for a variety of pond shapes and sizes, and could be deployed to characterize turbulence transfer rates and melting rates for ponds of simple shapes. Ponds with larger $R_{\mathrm{sb}}$ would generally melt more rapidly in horizontal direction at the expense of bottom melting, and tend to reduce turbulence transfer rates. Accordingly, ponds with small size, with enlongated boundaries, or with quite convoluted edge lines would have a relatively larger lateral growth rate compared with large, symmetric ponds. The melt pond geometry metrics and its size-evolution data presented by this paper provide a sound ground truth and initial forcing for their bulk pond model. For instance, assuming an arbitrary depth for our ponds (actually field data or an empirical equation would be the best), the ratio $R_{\mathrm{sb}}$ can be determined from Figures $6,8 \mathrm{~b}$, the shapes of melt ponds with varying sizes can be simplified as regular outlines (circular, rectangular, channel, or their combination) (Hohenegger and others (2012) with zigzags of different scale following the approach developed by Skyllingstad and Paulson (2007). The serrating of pond boundaries is to satisfy the values of $R_{\mathrm{sb}}$, convex degree, or fractal dimension manifested in Figure 7 . With these settings, the bulk model of melt pond evolution can run with atmospheric forcing (e.g. remote sensing data) to simulating the evolution of pond size and depth, hence a more precise scheme of albedo in climatological models. Also, our data can be used to validate and evaluate the model results. Undoubtedly, a sophisticated parameterization of ponds and albedo also requires more additional data such as detailed information on albedos of ponds of different depth and sea ice topography; and a great number of efforts are still needed to quantify the melt pond geomorphology and energy budget evolution.

The universal ice thinning and the emerging shifts from perennial to seasonal ice are reducing the reflection of solar irradiance by ice cover, emphasizing an enhanced absorption and transmission of the melt pond-sea ice system. Previous field campaigns indicated that the transmission of incident irradiance (especially for PAR band) through ponded ice was $\sim 2-5$ times larger than that through ambient bare melting ice (Perovich, 2005; Light and others, 2008; Ehn and others, 2011). Nicolaus and others (2012) concluded that melt pond formation is the key process accounting for a distinctly larger transmittance and absorbance of FYI than those of MYI. Light transmission through the ice cover was not only a function of surface properties and ice thickness (at scale $>1000 \mathrm{~m}^{2}$ ) but also of the size covered by a particular ice surface type like melt pond (Fig. 10), especially at a local scale (e.g. $<1000 \mathrm{~m}^{2}$ ) (Katlein and others, 2015). Assuming the incident solar radiation and the ice thickness is regionally homogeneous, the geometric variability and spatial distribution of surface types (leads, bare ice and ponded ice) causes a significant spatial heterogeneity in transmitted light fields in the upper ocean, which plays a pivotal role in primary productivity (Mundy and others, 2009; Arrigo and others, 2012), nutrient quality (Leu and others, 2010) and even the outgassing of

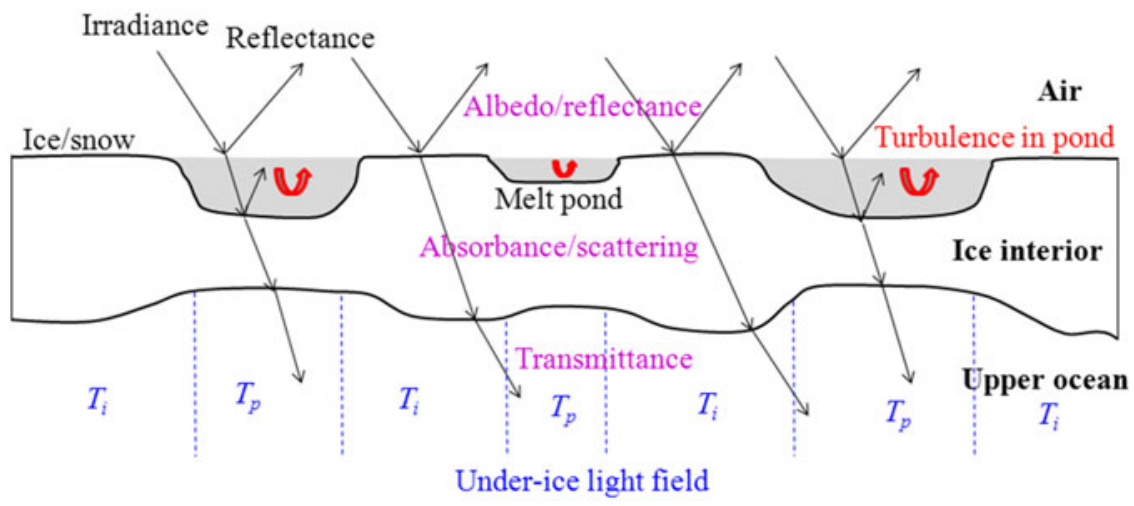

Fig. 10. Conceptual model of solar radiation partitioning in melt pond/ice matrix and heat transport induced by turbulences within ponds. The size and shape of melt pond influence the horizontal and vertical heat transport induced by the water turbulences (Skyllingstad and Paulson, 2007). The significant differences in transmitted light under ponded ice and bare ice/snow lead to a remarkable heterogeneity of solar radiation in the upper ocean ( $T_{\mathrm{p}}$ is $\sim 4-5$ times higher than $T_{\mathrm{i}}$ ) (Ehn and others, 2011). 
$\mathrm{CO}_{2}$ (Spencer and others, 2009). For instance, the melt pond geometry are demonstrated to have significant effects on the transmitted light fields in under-ice water using a simple edge spread function model (Fig. 10) (Ehn and others, 2011). With our spatial distribution data of melt pond geometry (size and shape), the spatial heterogeneity of transmitted light field under continuous floes can be assessed with the model mentioned above. However, although a pan-Arctic model provides a promising estimate of heat flux through sea ice assigning constant values to different ice types (MYI/FYI) (Arndt and Nicolaus, 2014), a lot of efforts have to be exerted to the investigations and quantification of the light transmittance, extinction, scattering and horizontal transport of melting sea ice, melt ponds and under-ice ocean water, and of the spatial distribution of ice thickness, ice properties (FYI or MYI), the proximity to each other surface types and even of the ice drift. A complicated 3-D radiative transfer model is also needed to represent the full spatial distribution of propagated light under natural surface conditions.

\section{SUMARRY AND CONCLUSIONS}

The Arctic sea ice cover undergoes a remarkable transformation from the vast expanse of snow-covered ice to the complex mosaics of ice and melt ponds during the melt season. Helicopter-based photography was conducted during the CHINARE2010 over MIZs and central Arctic Ocean, quantifying the size and geometry distributions of ice surface types, for instance bare ice, open water and melt ponds in an unusual sea ice reduction zone.

Our results show that the mean area fraction of open water and melt ponds in high Arctic $\left(84^{\circ} \mathrm{N}\right.$ to the north) in later summer 2010 was $\sim 25 \%$ and $6.8 \%$, respectively, but both with considerable deviations between flight paths and between images. The anomalous low ice concentration $(\sim 75 \%)$ provided a ground truth mapped in central Arctic by AMSR-E instruments in several summers, also called transpolar reduction (Kawaguchi and others, 2012). Overall, a minor latitudinal trend of ice concentration and melt pond coverage is identified.

Statistics on melt pond size and shape are presented based on more than 9200 ponds selected stochastically. Albeit at the peak period of melting of the year, the relatively small ponds were overwhelmingly predominant in numbers in both FYI and MYI. The probability densities of pond area distribution can be fitted favorably using power-law functions, with slight differences between ice types, and regionally. Some general relations of individual pond size with the basic indicators, including the roundness, convex degree, the ratio of perimeter to area and the fractal dimension derived from box-counting method of pond shape, are established empirically.

Additionally, the evolution of melt pond size and geometry is discussed based on four stages. As the melting progresses, melt pond geomorphology transforms from small pond with simple edge line to quite complex ramified network. Nevertheless, a large number of small simple melt ponds persistently remain and form. A universal separation of length scale in pond structure is demonstrated using an alternative fractal dimension for melt pond group determined from the area-perimeter datasets.

We believe that the present results would help the development of a more realistic melt pond model, and the quantitative evaluation of the heterogeneity of transmitted radiation under the ice bottom. Although the spatial variability and seasonality of the pan-Arctic Ocean have been estimated using simple up-scaling approach (Nicolaus and others, 2012; Arndt and Nicolaus, 2014; Katlein and others, 2015), substantial efforts have to be made in field measurements of ice properties, such as the interior structure, permeability and the light extinction, scattering and transmittance. Moreover, aerial photography is a widely employed and effective method to observe melt ponds on Arctic sea ice (e.g. Perovich and others, 2002b; Sankelo and others, 2010), providing a snapshot of melt pond with very high resolutions but at a local scale. The truncation error induced by the limited image coverage is not a big problem because the size of melt pond is always much less than the image coverage, in contrary to the floe size distribution where the size of large ice floes is generally beyond the scope of an image and then the truncation error cannot be ignored ( $\mathrm{Lu}$ and others 2008). Overlapping photography can partly enlarge the image coverage in the direction along flight track, but it is always limited by the aircraft conditions during field investigations. Combination with satellite remote sensing is another means to increase the spatial scale of view. Our areal fraction and geometry metrics of melt pond can also be used to validate and assess the recently developed algorithms for retrieving melt pond fraction from optical MODIS products and melt pond fraction and geometry from promising SAR images.

\section{ACKNOWLEDGEMENTS}

This study was supported by the National Nature Science Foundation of China (Nos. 41402203, 41276191 and 41376186), and the Chinese Polar Environment Comprehensive Investigation and Assessment Programs (No.CHINARE2015-04-03). The authors are grateful to the crew of the helicopter for their help during fieldwork. The AMSR-E/ASI ice concentration data is available at http://www.iup.uni-bremen.de:8084/amsr/ amsre.html. Research groups, who would like to use the presented dataset, should contact the authors, W Huang (huangwenfeng@chd.edu.cn) and P Lu (lupeng@dlut.edu.cn).

\section{REFERENCES}

Arndt S and Nicolaus M (2014) Seasonal cycle and long-term trend of solar energy fluxes through Arctic sea ice. Cryosphere, 8 , 2219-2233 (doi: 10.5194/tc-8-2219-2014)

Arrigo KR and 30 others (2012) Massive phytoplankton blooms under Arctic sea ice. Science, 336, 1408 (doi: 10.1126/ science.1215065)

Barber DG and Yackel J (1999) The physical, radiative and microwave scattering characteristics of melt ponds on Arctic landfast sea ice. Int. J. Remote Sens., 20(10), 2069-2090

Curry JA, Schramm JL, Perovich DK and Pinto JO (2001) Applications of SHEBA/FIRE data to evaluation of snow/ice albedo parameterizations. J. Geophys. Res., 106(D14), 1534515355

Darby DA, Myers WB, Jakobsson M and Rigor I (2011) Modern dirty sea ice characteristics and sources: the role of anchor ice. J. Geophys. Res., 116, C09008 (doi: 10.1029/2010JC006675)

Downing JA and 10 others (2006) The global abundance and size distribution of lakes, ponds, and impoundments. Limnol. Oceanogr., 51(5), 2388-2397 (doi: 10.4319/lo.2006.51.5.2388)

Ehn JK and 5 others (2011) Impact of horizontal spreading on light propagation in melt pond covered seasonal sea ice in the Canadian Arctic. J. Geophys. Res., 166, C00G02 (doi: 10.1029/ 2010JC006908) 
Eicken H (2013) Arctic sea ice needs better forecasts. Nature, 497, 431-433 (doi: 10.1038/497431a)

Eicken H, Krouse HR, Kadko D and Perovich DK (2002) Tracer studies of pathways and rates of meltwater transport through Arctic summer sea ice. J. Geophys. Res., 107(C10), 8046 (doi: 10.1029/2000JC000583)

Eicken H, Grenfell TC, Perovich DK, Richter-Menge JA and Frey K (2004) Hydraulic controls of summer Arctic pack ice albedo. J. Geophys. Res., 109, C08007 (doi: 10.1029/2003JC001989)

Eicken $\mathrm{H}$ and 5 others (2005) Sediment transport by sea ice in the Chukchi and Beaufort Seas: increasing importance due to changing ice conditions? Deep Sea Res. Pt. II, 52, 3281-3302 (doi: 10.1016/j.dsr2.2005.10.006)

Flocco D and Feltham DL (2007) A continuum model of melt pond evolution on Arctic sea ice. J. Geophys. Res., 112, C08016 (doi: 10.1029/2006JC003836)

Flocco D, Schroeder D, Feltham DL and Hunke EC (2012) Impact of melt ponds on Arctic sea ice simulations from 1990 to 2007. J. Geophys. Res., 117, C09032 (doi: 10.1029/2012JC008195)

Frey KE, Perovich DK and Light B (2011) The spatial distribution of solar radiation under a melting Arctic sea ice cover. Geophys. Res. Lett., 35, L22501 (doi: 10.1029/2011GL049421)

Hohenegger C, Alali B, Steffen KR, Perovich DK and Golden KM (2012) Transition in the fractal geometry of Arctic melt ponds. Cryosphere, 6, 1157-1162 (doi: 10.5194/tc-6-1157-2012)

Huang W, Li Z, Wang Y and Lei R (2011) A concept for autonomous and continuous observation of melt pond morphology: instrument design and test trail during the 4th CHINARE-Arctic in 2010. Adv. Polar Sci., 22(4), 273-280 (doi: 10.3724/SP. J.1085.2011.00273)

Huang W and 5 others (2013) The physical structures of snow and sea ice in the Arctic section of $150^{\circ}-180^{\circ} \mathrm{W}$ during the summer of 2010. Acta Oceanol. Sin., 32(5), 1-11 (doi: 10.1007/ s13131-013-0301-9)

Inoue J, Curry JA and Maslanik JA (2008a) Application of Aerosondes to melt-pond observations over Arctic sea ice. J. Atmos. Ocean. Technol., 25, 327-334 (doi: 10.1175/2007JTECHA955.1)

Inoue J, Kikuchi T and Perovich DK (2008b) Effect of heat transmission through melt ponds and ice on melting during summer in the Arctic Ocean. J. Geophys. Res., 113, C05020 (doi: 10.1029/ 2007JC004182)

Istomina $L$ and 11 others (2014) The melt pond fraction and spectral sea ice albedo retrieval from MERIS data: validation and trends of sea ice albedo and melt pond fraction in the Arctic for years 2002-2011. Cryosphere Discuss, 8, 5227-5292 (doi: 10.5194/ tcd-8-5227-20114)

Katlein C and 11 others (2015) Influence of ice thickness and surface properties on light transmission through Arctic sea ice. J. Geophys. Res., 102(C9), 5932-5944 (doi: 10.1002/2015JC010914)

Kawaguchi Y, Hutchings JK, Kikuchi T, Morison JH and Krishfield RA (2012) Anomalous sea-ice reduction in the Eurasian Basin of the Arctic Ocean during summer 2010. Polar Sci., 6, 39-53 (doi: 10.1016/j.polar.2011.11.003

Kim D-J and 5 others (2013) Melt pond mapping with high-resolution SAR: the first view. Proc. IEEE Trans. Geosci. Remote Sens., 101(3), 748-758 (doi: 10.1109/PROC.2012.2226411)

Kinnard C, Zdanowicz CM, Koerner RM and Fisher DA (2008) A changing Arctic seasonal ice zone: observations from 18702003 and possible oceanographic consequences. Geophys. Res. Lett., 35, L02507 (doi: 10.1029/2007GL032507)

Krumpen T and 5 others (2011) HELIOS, a nadir-looking sea ice monitoring camera. Cold Reg. Sci. Technol., 65(3), 308-313 (doi: 10.1016/j.coldregions.2010.11.007)

Laxon SW and 14 others (2013) CryoSat-2 estimates of Arctic sea ice thickness and volume. Geophys. Res. Lett., 40, 1-6 (doi: 10.1002/grl.50193)

Lei R and 5 others (2012) Reflection and transmission of irradiance by snow and sea ice in the central Arctic Ocean in summer 2010. Polar Res., 31, 1-17 (doi: 10.3402/polar.v31i0.17325)
Lei $\mathrm{R}$ and 5 others (2014) Multiyear sea-ice thermal regimes and oceanic heat flux derived from an ice mass balance buoy in the Arctic Ocean. J. Geophys. Res., 119 (doi: 10.1002/2012JC008731)

Leu E, Wiktor J, Soreide JE, Berge J and Falk-Peterson S (2010) Increased irradiance reduced food quality of sea ice algae. Mar. Ecol. Prog. Ser., 411, 49-60

Light B, Grenfell TC and Perovich DK (2008) Transmission and absorption of solar radiation by Arctic sea ice during the melt season. J. Geophys. Res., 113, C03023 (doi: 10.1029/2006JC003977)

Lu P, Li ZJ, Zhang ZH and Dong XL (2008) Aerial observations of floe size distribution in the marginal ice zone of summer Prydz Bay. J. Geophys. Res., 113, C01011 (doi: 10.1029/2006JC003965)

Lu P, Li Z, Cheng B, Lei R and Zhang R (2010) Sea ice surface features in Arctic summer 2008: aerial observations. Remote Sens. Environ., 114, 693-699 (doi: 10.1016/j.rse.2009.11.009)

Lu P, Li Z, Lei R and Zhang R (2011) Aerial observations of melt pond distributions in arctic summer 2008. In Proceedings of the Twenty-first International Offshore and Polar Engineering Conference, 19-24 June 2011. International Society of Offshore and Polar Engineers, Maui, Hawaii, USA, 948-952

Mäkynen M, Kern S, Rösel A and Pedersen LT (2014) On the estimation of melt pond fraction on the Arctic sea ice with ENVISAT WSM images. IEEE Trans. Geosci. Remote Sens., 52(11), 73667379 (doi: 10.1109/TGRS.2014.2311476)

Markus T, Cavalieri DJ, Tschudi MA and Ivanoff A (2003) Comparison of aerial video and Landsat 7 data over ponded sea ice. Remote Sens. Environ., 86, 458-469 (doi: 10.1016/ S0034-4257(03)00124-X)

Miao X, Xie H, Ackley SF, Perovich DK and Ke C (2015) Objectbased detection of Arctic sea ice and melt ponds using high spatial resolution aerial photographs. Cold Reg. Sci. Technol., 119, 211-222 (doi: 10.1016/j.coldregions.2015.06.014)

Morassutti MP and LeDrew EF (1996) Albedo and depth of melt ponds on sea-ice. Int. J. Climatol., 16, 817-838

Mundy CJ, Barber DG, Michel C and Marsden RF (2007) Linking ice structure and microscale variability of algal biomass in Arctic first-year sea ice using an in situ photographic technique. Polar Biol., 30, 1099-1114 (doi: 10.1007/s00300-007-0267-1)

Mundy CJ and 13 others (2009) Contribution of under-ice primary production to an ice-edge upwelling phytoplankton bloom in the Canadian Beaufort Sea. Geophys. Res. Lett., 36, L17601 (doi: 10.1029/2009GL038837)

Mundy CJ and 11 others (2011) Characteristics of two distinct highlight acclimated algal communities during advanced stages of sea ice melt. Polar Biol., 34, 1869-1886 (doi: 10.1007/s00300011-0998-x)

Nicolaus M, Katlein C, Maslanik J and Hendricks S (2012) Changes in Arctic sea ice result in increasing light transmittance and absorption. Geophys. Res. Lett., 39, L24501 (doi: 10.1029/2012GL053738)

Ogi M and Rigor IG (2013) Treads in Arctic sea ice and the role of atmospheric circulation. Atmos. Sci. Lett., 14(2), 97-101 (doi: 10.1002/asl2.423)

Palmer MA, Saenz BT and Arrigo KR (2014) Impacts of sea ice retreat, thinning, and melt-pond proliferation on the summer phytoplankton bloom in the Chukchi Sea. Arctic Ocean, Deep Sea Res. II, 105, 85-104 (doi: 10.1016/j.dsr2.2014.03.016)

Pedersen CA and 5 others (2009) Combined airborne profiling over Fram Strait sea ice: fractional sea-ice types, albedo and thickness measurements. Cold Reg. Sci. Technol., 55, 23-32 (doi: 10.1016/ j.coldregions.2008.08.004)

Perovich DK (2005) On the aggregate-scale partitioning of solar radiation in Arctic sea ice during the Surface Heat Budget of the Arctic Ocean (SHEBA) field experiments. J. Geophys. Res., 110 (C3) (doi: 10.1029/2004JC002512)

Perovich DK and Polashenski C (2012) Albedo evolution of seasonal Arctic sea ice. Geophys. Res. Lett., 39, L08501 (doi: 10.1029/ 2012GL051432)

Perovich DK and 22 others (1999) Year on ice gives climate insights. Eos Trans. AGU, 80(481), 485-486 
Perovich DK, Grenfell TC, Light B and Hobbs PV (2002a) Seasonal evolution of the albedo of multiyear Arctic sea ice. J. Geophys. Res., 107(C10), 8044 (doi: 10.1029/2000JC000438)

Perovich DK, Tucker WB, III and Ligett KA (2002b) Aerial observations of the evolution of ice surface conditions during summer. J. Geophys. Res., 107(C10), 8048 (doi: 10.1029/2000JC000449)

Perovich DK and 5 others (2003) Thin and thiner: Sea ice mass balance measurements during SHEBA. J. Geophys. Res., 108 (C3) (doi: 10.1029/2002JC001079)

Polashenski C, Perovich DK and Courville Z (2012) The mechanisms of sea ice melt pond formation and evolution. J. Geophys. Res., 117, C01001 (doi: 10.1029/2011JC007231)

Renner AHH, Dumont M, Beckers J, Gerland S and Haas C (2013) Improved characterization of sea ice using simultaneous aerial photography and sea ice thickness measurements. Cold Reg. Sci. Technol., 92, 37-47 (doi: 10.1016/j.coldregions.2013.03.009)

Roeckner E, Mauritsen T, Esch M and Brokopf R (2012) Impact of melt ponds on Arctic sea ice in past and future climate as simulated by MPI-ESM. J. Adv. Model. Earth Syst., 4, M00A02 (doi: 10.1029/2012MS000157)

Rösel A and Kaleschke L (2012) Exceptional melt pond occurrence in the years 2007 and 2011 on the Arctic sea ice revealed from MODIS satellite data. J. Geophys. Res., 117, C05018 (doi: 10.1029/2011JC007869)

Rösel A, Kaleschke L and Birnbaum G (2012) Melt ponds on Arctic sea ice determined from MODIS satellite data using an artificial neural network. Cryosphere, 6, 431-446 (doi: 10.5194/tc-6-431-2012)

Sankelo P, Haapala J, Heiler I and Rinne E (2010) Meld pond formation and temporal evolution at the drifting station Tara during summer 2007. Polar Res., 29, 311-321 (doi: 10.1111/j.17518369.2010.00161.x)

Scharien RK, Hochheim K, Landy J and Barber DG (2014a) First-year sea ice melt pond fraction estimation from dual-polarisation Cband SAR-Part 2: scaling in situ to Radarsat-2. Cryosphere, 8, 2163-2176 (doi: 10.5194/tc-8-2163-2014)

Scharien RK, Landy J and Barber DG (2014b) First-year sea ice melt pond fraction estimation from dual-polarisation C-band SAR-Part 1: in situ observations. Cryosphere, 8, 2147-2162 (doi: 10.5194/ tc-8-2147-2014)

Scott F and Feltham DL (2010) A model of the three-dimensional evolution of Arctic melt ponds on first-year and multiyear sea ice. J. Geophys. Res., 115, C12064 (doi: 10.1029/2010JC006156)

Seekell DA and Pace ML (2011) Does the Pareto distribution adequately describe the size-distribution of lakes? Limnol. Oceanogr., 56(1), 350-356 (doi: 10.4319/lo.2011.56.1.0350)

Seekell DA, Pace ML, Tranvik LJ and Verpoorter C (2013) A fractalbased approach to lake size-distributions. Geophys. Res.Lett., 40, 1-5 (doi: 10.1029/grl.50139)

Skyllingstad ED and Paulson CA (2007) A numerical study of melt ponds. I. Geophys. Res., 112, C08015 (doi: 10.1029/2006JC003729)

Skyllingstad ED, Paulson CA and Perovich DK (2009) Simulation of melt pond evolution on level ice. J. Geophys. Res., 114, C12019 (doi: 10.1029/2009JC005363)

Spencer RG and 10 others (2009) Photochemical degradation of dissolved organic matter and dissolved lignin phenols from the Congo River. J. Geophys. Res., 114, G03010 (doi: 10.1029/ 2009JG000968)
Stocker TF and 9 others (eds) (2013) Climate Change 2013: The Physical Science Basis: Working Group I Contribution to the Fourth Assessment Report of the Intergovernmental Panel on Climate Change. Cambridge Univ. Press, New York.

Taylor PD and Feltham DL (2004) A model of melt pond evolution on sea ice. J. Geophys. Res., 109, C12007 (doi: 10.1029/ 2004JC002361)

Tietsche S and 8 others (2014) Seasonal to interannual Arctic sea ice predictability in current global climate models. Geophys. Res. Lett., 41, 1035-1043 (doi: 10.1002/2013GL058755)

Toyota T, Haas C and Tamura T (2011) Size distribution and shape properties of relatively small sea-ice floes in the Antarctic marginal ice zone in late winter. Deep Sea Res. Part II, 58(9), 11821193 (doi: 10.1016/j.dsr2.2010.10.034)

Tschudi MA, Curry JA and Maslanik JA (2001) Airborne observations of summertime surface features and their effect on surface albedo during FIRE/SHEBA. J. Geophys. Res., 106(D14), 15335-15344

Tschudi MA, Maslanik JA and Perovich DK (2008) Derivation of melt pond coverage on Arctic sea ice using MODIS observations. Remote Sens. Environ., 112, 2605-2614 (doi: 10.1016/j. res.2007.12.009)

Vancoppenolle $M$ and 11 others (2013) Role of sea ice in global biogeochemical cycles: emerging views and challenges. Quaternary Sci. Rev., 79, 207-230 (doi: 10.1016/j.quascirev.2013.04.011)

Wang J, Guo J, Wang H, Sun B and Tian G (2012) Data analysis of shipborne EM31-ICE measuring in China's fourth Arctic scientific expedition. Adv. Polar Sci., 24(1), 47-52 (doi: 10.3724/SP. J.1084.2012.00047)

Webster MA and 5 others (2015) Seasonal evolution of melt ponds on Arctic sea ice. J. Geophys. Res., 120(C9), 5968-5982 (doi: 10.1002/2015JC011030)

Weissling B, Ackley S, Wagner P and Xie H (2009) EISCAM - digital image acquisition and processing for sea ice parameters from ships. Cold Reg. Sci. Technol., 57, 49-60 (doi: 10.1016/j. coldregions.2009.01.001)

Xia W, Xie H and Ke C (2014) Assessing trend and variation of Arctic sea ice extent during 1979-2012 from a latitude perspective of ice edge. Polar Res., 33, 21249 (doi: 10.3402/polar.v33.21249)

Xia W and 5 others (2015) Summer surface albedo of sea ice in Pacific Arctic Sector as measured during the CHINARE 2010 cruise. Art. Antarct. Alp. Res., 47(4), 645-656 (doi: 10.1657/ AAAR0014-090)

Xie $\mathrm{H}$ and 6 others (2013) Summer sea ice characteristics and morphology in the Pacific Arctic sector as observed during the CHINARE 2010 cruise. Cryosphere, 7, 1057-1072 (doi: 10.5194/tb-7-1057-2013)

Yackel JJ and Barber DG (2000) Melt ponds on sea ice in the Canadian Archipelago 2. On the use of RADARSAT-1 synthetic aperture radar for geophysical inversion. /. Geophys. Res., 105 (C9), 22 061-22 070

Yackel JJ, Barber DG and Manesiak JM (2000) Melt ponds on sea ice in the Canadian Archipelago 1. Variability in morphological and ratiative properties. J. Geophys. Res., 105(C9), 22 049-22 060

Zhang G, Yao T, Xie H, Zhang K and Zhu F (2014) The state and abundance of lakes across the Tibetan Plateau. Chin. Sci. Bull., 59(24), 3010-3021 (doi: 10.1007/s11434-014-0258-x) 